\title{
ANTI-ENDOTHELIAL CELL ANTIBODIES AND CENTRAL NERVOUS SYSTEM INVOLVEMENT IN BEHÇET'S DISEASE
}

Romy Christmann Souza, Laís Lage, Cláudia Goldesntein-Schainberg, André Regis Macedo, Solange Carrasco, Célio Roberto Gonçalves

Christmann de Souza RB, Lage L, Goldenstein-Schainberg C, Macedo AR, Carrasco S, Gonçalves CR. Anti-endothelial cell antibodies and central nervous system involvement in Behçet's disease. Clinics. 2007; 62(6):685-90.

INTRODUCTION: Previous studies have detected the presence of anti-endothelial cell antibodies (AECA) in patients with Behçet's disease (BD). However, no real evidence exists whether these antibodies exert any influence on clinical presentation and/or activity of this disease.

OBJECTIVES: To determine the frequency of AECA in patients with BD and analyze possible clinical associations.

METHODS: 50 patients with BD who fulfilled diagnostic criteria were selected. Thirty-seven patients were females, and 13 were males; the mean age was $44 \pm 9$ years with a mean follow-up time of $10 \pm 7.5$ years. AECA were assayed by ELISA using ECV-304 cells as the antigenic substrate. The prevalence of AECA was determined, and their possible relationships with present and past clinical features were investigated.

RESULTS: AECA were detected in the sera of $38 \%$ of the patients (IgG in 13, IgM in four, and IgG plus IgM in two). An association was observed between AECA and a previous history of central nervous system involvement $(\mathrm{OR}=5.4, \mathrm{p}=0.03)$. This association was more evident for IgG-AECA $(\mathrm{OR}=6.0, \mathrm{p}=0.02)$. A trend of an increased risk of aneurysms was also observed in patients with $\operatorname{IgG}$-AECA $(\mathrm{OR}=2.58, \mathrm{p}=0.77)$. None of the other clinical characteristics showed a relevant association with these antibodies.

CONCLUSION: Our data suggest that IgG-AECA may be a marker of more severe lesions in patients with BD based on the higher frequency of previous central nervous system manifestations in patients who presently display circulating AECA.

KEYWORDS: Behçet's Disease, Anti-endothelial cell antibody. Central nervous system. Prevalence. Clinical disease activity

\section{INTRODUCTION}

Behçet's disease (BD) is an idiopathic, multisystem, chronic, and recurrent inflammatory disease characterized by major symptoms of recurrent oral and genital ulceration, uveitis, and erythema nodosum. Involvement of the intestines, vessels, and central nervous system (CNS) sometimes leads to a poor prognosis. The disease runs a chronic course-with unpredictable exacerbations and remissions

Department of Internal Medicine, Rheumatology Clinic, Hospital das Clínicas, Faculdade de Medicina, Universidade de São Paulo, São Paulo, SP - Brazil Email: romy.c@uol.com.br

Received for publication on June 11, 2007

Accepted for publication on August 08, 2007 whose frequency and severity may diminish with timeand can affect both genders with a worldwide distribution. ${ }^{1}$

Vasculitis is thought to underlie the clinical manifestation of $\mathrm{BD}^{2-4}$ This vasculitis is distinctive because it involves both arteries and veins of all sizes. ${ }^{5}$ These data suggest the existence of a hypercoagulable state and, therefore, a possible role for the endothelium in the pathogenesis of BD. Indeed, extensive evidence for impaired endothelial cell function is accumulating, and a role for vascular inflammation and impaired oxidative stress has been suggested. ${ }^{2-5}$ Circulating factors may be important because sera from patients with Behçet syndrome in both active and inactive states have been reported to depress nitric oxide production in cultured endothelial cells. ${ }^{6} \mathrm{~Pa}-$ tients may also show evidence of endothelial cell activation and hypercoagulability. ${ }^{7,8}$ Multiple vessel-related complica- 
tions, including thromboses, stenosis, occlusions, and aneurysms, can affect BD patients. A number of factors may contribute to thrombosis in individual cases, but the primary reason for clots seems to reside in the inflammatory process in the arterial wall, which is still incompletely understood. ${ }^{9}$

It is well established in the literature that endothelial cells play an important role in the pathology of vasculitic disorders. ${ }^{5,7}$ In this regard, the presence of autoantibodies, mainly of the IgG class, that recognize antigens expressed on endothelial cells have been increasingly demonstrated over the last few years in a variety of diseases such as systemic lupus erythematosus (SLE), systemic sclerosis (SSc), rheumatoid arthritis (RA), microscopic polyangiitis, Kawasaki disease, and Wegener's granulomatosis, among others. ${ }^{10-17}$

Specifically in BD, some studies have shown that a circulating immunoglobulin that is able to bind to the endothelium, called anti-endothelial cell antibodies (AECA), might be present. However, no real evidence exists whether these specific antibodies exert any influence on clinical presentation and/or activity of the disease..$^{11,12,18,19}$

Therefore, the purpose of the present study was to verify the prevalence of AECA in BD and analyze possible associations between these antibodies and clinical characteristics of this disease.

\section{PATIENTS AND METHODS}

In a six month period, 50 consecutive BD patients regularly attending our outpatient clinic were interviewed and had their files revised. All patients (100\%) fulfilled the International Study Group for Behçet Disease classification criteria for $\mathrm{BD}^{20}$ and signed an informed consent form on the day of their routine visit. Blood samples were collected from all 50 patients.

Thirty-seven patients were female (74\%), and 13 were (26\%) males, aged 24 to 66 years (mean of $44 \pm 9$ years). The mean age at diagnosis was $33 \pm 8$ years (18 to 53 years), and mean follow-up time was $10 \pm 7.5$ years ( 1 to 30 years).

Besides bipolar ulcers reported by all patients, pseudofolliculitis (66\%), articular involvement (54\%), inflammatory ocular lesions (54\%), and erythema nodosum (52\%) were the most common clinical features reported by this group of patients (Table 1). Regarding inflammatory ocular events, uveitis was largely the most common manifestation, indicated by $25(50 \%)$ of the 50 patients, whereas conjunctivitis was noted by only two patients. Past history of joint involvement, predominantly of ankles and knees, was described as arthralgia by five patients and arthritis by 22 patients.

Previous neurological involvement was detected in $20 \%$ of these patients; $40 \%$ of these manifested as aseptic meningitis, followed by retinal vasculitis in 2 cases and facial
Table 1 - Clinical features of the 50 Behçet Disease patients in this study.

\begin{tabular}{|c|c|}
\hline Age (years) ${ }^{1}$ & $44 \pm 9(24-66)$ \\
\hline Age at diagnosis (years) ${ }^{1}$ & $33 \pm 8(18-53)$ \\
\hline Follow-up duration (years) ${ }^{1}$ & $10 \pm 7.5(1-20)$ \\
\hline Active disease & $23(46 \%)$ \\
\hline \multicolumn{2}{|l|}{ Previous involvement, $\mathrm{N}(\%)$} \\
\hline Oral ulcers & $50(100 \%)$ \\
\hline Pseudofolliculitis & $33(66 \%)$ \\
\hline Articular ${ }^{2}$ & $27(54 \%)$ \\
\hline Erythema nodosum & $26(52 \%)$ \\
\hline Uveitis & $25(50 \%)$ \\
\hline Deep venous thrombosis ${ }^{3}$ & $8(16 \%)$ \\
\hline Arterial and superficial venous thrombosis & $5(10 \%)$ \\
\hline Aneurysm $^{4}$ & $2(4 \%)$ \\
\hline Neurological involvement ${ }^{5}$ & $10(20 \%)$ \\
\hline
\end{tabular}

${ }^{1}$ Mean \pm standard deviation (range).

${ }^{2}$ Arthritis in $82 \%$.

${ }^{3}$ Involvement of the lower limbs in 5 patients.

${ }^{4}$ One radial artery aneurysm and one central nervous system aneurysm.

${ }^{5}$ Including aseptic meningitis in 5 patients.

paralysis, intracranial hypertension (brain pseudo-tumor), and seizures in one case each.

Previous deep venous thrombosis was notified by $16 \%$ of patients, superficial venous thrombosis in $10 \%$ and arterial thrombosis was previously detected also in $10 \%$ of patients.

Clinical disease activity was defined when at least one major criterion and one minor criterion were present. Major criteria included oral ulcer, genital ulcer, cutaneous lesions (pseudo-folliculitis, erythema nodosum), and ocular active lesions, while minor criteria included the presence of arthralgia, arthritis, involvement of the central nervous system (CNS) or gastrointestinal tract, and recent thrombosis.

Twenty-three patients were considered to be currently on clinical disease activity $(23 \%)$, with oral ulcers as the most common manifestations $(36 \%)$, followed by pseudofolliculitis (16\%) associated with articular involvement in $14 \%$ of cases.

\section{Endothelial cell ELISA}

ECV-304 endothelial cells were used to identify the antiendothelial antibody, a method previously described in several studies. ${ }^{21-23}$ These cells were expanded in plastic flasks appropriate for cell culture and seeded onto sterile polystyrene $96-w e l l ~(6 \mathrm{~mm}$ in diameter) microplates at a concentration of $2 \times 10^{4}$ cells/well in $100 \mu \mathrm{l}$ medium 199 containing $10 \%$ fetal bovine serum. After culture for 24 to 48 hours at $37^{\circ} \mathrm{C}$ in an incubator in a $5 \% \mathrm{CO}_{2}$ atmosphere, the plates were washed twice with magnesium-containing Hank's solution, fixed with $0.1 \%$ glutaraldehyde for $10 \mathrm{~min}$ at $4^{\circ} \mathrm{C}$, and then washed with distilled water. Next, $100 \mu \mathrm{l}$ 
$2 \%$ bovine serum albumin (BSA) in PBS was added to each well to block non-specific immunoglobulin receptors, and the plates were incubated for 2 hour at $37^{\circ} \mathrm{C}$.

After three washes with PBS, test serum diluted 1/200 in PBS-2\%BSA were plated in duplicate and incubated for 2 hours at $37^{\circ} \mathrm{C}$. After a new cycle of three washes, $100 \mu \mathrm{l}$ PBS-2\%BSA containing alkaline phosphatase-conjugated human anti-IgG or anti-IgM was added to each well and incubated for 1 hour at $37^{\circ} \mathrm{C}$.

After a new cycle of three washes with PBS, $100 \mu \mathrm{l}$ nitrophenyl phosphate at a concentration of $1 \mathrm{mg} / \mathrm{ml}$ in $10 \%$ $(\mathrm{v} / \mathrm{v})$ di-ethanol-amine buffer, $\mathrm{pH} 9.8$, was added to each well, and absorbance was read every 15 min with an ELISA spectrophotometer. The reaction was stopped when the standard serum reached an optical density $(\mathrm{OD})=1$.

Each plate contained two positive sera as standards, and two aliquots of 60 pooled normal sera with known OD were used as negative controls. A serum was considered positive when the OD was superior to the mean OD of negative control sera plus three standard deviations.

\section{Statistical analysis}

Non-parametric data were compared between groups by the chi-square test with Yates correction. Student's t-test was used to compare parametric data, with the level of significance set at 5\%. An odds ratio (OR) was calculated using a $95 \%$ confidence interval (CI), and statistical significance was considered relevant when $\mathrm{p}<0.05$.

\section{RESULTS}

AECA were detected in 19 (38\%) patients, 13 had IgGAECA, four IgM-AECA, and two patients had both IgG and IgM-AECA. In this series, no association was found between the presence of AECA and clinical disease activity. Only four out of the 23 patients currently with clinical disease activity had positive AECA (OR 0.16; $>0.05$ ) (Table 2).

Our results showed a positive association between previous CNS involvement and the presence of circulating AECA ( $p=0.03$; OR=5.4). Interestingly, this association was more evident with the $\operatorname{IgG}$ isotype (OR $=6, \mathrm{p}=0.02,95 \%$ CI) but was less significant when IgM-AECA was taken into account $(\mathrm{OR}=2.33, \mathrm{p}>0.05,95 \% \mathrm{CI})$.

A trend toward increased risk for aneurysms was also observed in patients with IgG-AECA $(\mathrm{OR}=2.58, \mathrm{p}=0.77)$, which was not statistically significant probably due to the small number of cases reported (only two cases). In this series, no other clinical association was found between positive AECA and present or past clinical BD manifestation.

Almost all patients, except six cases (12\%), were on a
Table 2 - Presence of AECA and correlation with both previous clinical involvement and current clinical disease activity.

\begin{tabular}{lcccc}
\hline \multirow{2}{*}{ Previous clinical involvement } & Total (\%) & AECA + & OR & $p$ \\
\hline Central nervous system & $10(20 \%)$ & 7 & 5.4 & $\mathrm{p}=0.03$ \\
Folliculitis & $33(66 \%)$ & 11 & 1.66 & $\mathrm{NS}$ \\
Articular & $27(54 \%)$ & 10 & 1.5 & $\mathrm{NS}$ \\
Erythema nodosum & $26(52 \%)$ & 9 & 0.74 & $\mathrm{NS}$ \\
Uveitis & $25(50 \%)$ & 11 & 1.66 & $\mathrm{NS}$ \\
Superficial venous thrombosis & $5(10 \%)$ & 0 & - & - \\
Deep venous thrombosis & $8(16 \%)$ & 2 & 0.78 & $\mathrm{NS}$ \\
Arterial thrombosis & $5(10 \%)$ & 2 & 1.13 & $\mathrm{NS}$ \\
Aneurysm & $2(4 \%)$ & 1 & 2.58 & $\mathrm{NS}$ \\
Current clinical activity & $23(46 \%)$ & 4 & 0.16 & $\mathrm{NS}$ \\
\hline
\end{tabular}

AECA $=$ anti-endothelial cell antibody; $\mathrm{OR}=$ odds ratio. $95 \% \mathrm{CI}$; NS = not significant ( $\mathrm{p}<0.05$ was considered significant).

treatment specifically for BD (including prednisone, azathioprine, thalidomide, cyclosporine, colchicine, cyclophosphamide, chlorambucil, and methotrexate). The majority (34\%) was taking only one drug $(\mathrm{n}=17)$, almost one third (30\%) were treated with more than two drugs, and twelve patients (24\%) were taking up to two drugs simultaneously. The most common drug used was colchicine (41 patients), followed by prednisone ( 24 patients). Cyclosporine ( 8 patients), azathioprine (7 patients) and thalidomide (4 patients) were also frequently used. Cyclophosphamide, chlorambucil, and methotrexate were prescribed for one patient each. Among the 50 patients analyzed, 23 were considered clinically active. All were on treatment and twelve of them (52\%) were taking more than two drugs. Six patients (26\%) were being treated with only one drug, and five patients (21\%) were taking two drugs concurrently.

\section{DISCUSSION}

Antibodies to endothelial cells have been described in a variety of vasculitic disorders and were detected in $38 \%$ of our patients with BD. For the first time in the literature, we observed an important association between the presence of AECA and previous CNS involvement in BD patients, with aseptic meningitis as the most frequent lesion.

AECA are a heterogeneous group of antibodies directed against the endothelial cell membranes. ${ }^{10,11,15}$ The exact involvement of AECA in autoimmune diseases and vascular manifestations in general is still poorly defined. Numerous target antigens for these antibodies have been identified, including DNA, ribosomal proteins, fibronectin, and others. ${ }^{15}$

Several investigators have demonstrated that AECA do not have cytolytic activity against endothelial cells in patients with autoimmune diseases. ${ }^{13,18}$ Others, though, have observed that AECA may initiate complement binding and disrupt en- 
dothelial cells in culture cells from SLE and SSc patients. ${ }^{14,15}$ In this regard, experimental in vitro and in vivo models support a potential pathogenic role for AECA in sustaining immune-mediated vessel inflammation. Rather than being cytotoxic to endothelial cells, AECA are able to up-regulate the expression of adhesion molecules (E-selectin, intercellular adhesion molecule-1, and vascular cell adhesion molecule1) and induce the secretion of cytokines and chemokines that cause leukocyte recruitment and adhesion in turn. ${ }^{24}$ Furthermore, a recent idiotypic animal model has provided further evidence that AECA can be pathogenic. ${ }^{25}$ These observations suggest that vasculitis is associated with pathologic activation of normal immune cell cytokine cascades. Abnormal expression of adhesion molecules and cytokines in vascular endothelium is a manifestation of endothelial dysfunction that can be triggered by a variety of stimuli, including infectious agents, immune complexes, and anti-endothelial cell antibodies. $^{26,27}$ Deregulated adhesion molecule expression, uncontrolled inflammation, thrombosis, and vessel occlusion might lead to the clinical manifestations of vasculitic.

AECA have been increasingly demonstrated in a variety of diseases such as SLE, SSc, RA, microscopic polyangiitis, Kawasaki disease, and Wegner's granulomatosis, among others. ${ }^{10-17}$ In SLE and systemic vasculitis, AECA increased interleukins like IL-1, IL-6 and IL- $8^{16}$ and may be more frequent in sera of patients with active disease $^{12}$. Although RA is a multisystemic inflammatory disease, AECA is not a marker of this specific disease activity. Nevertheless, the presence of AECA is mostly detected in those cases complicated by vasculitis. ${ }^{13}$

In $\mathrm{BD}$, other investigations have found a prevalence of positive AECA that ranged from 18.1 to $50 \%$ of the patients analyzed. ${ }^{11,12,18,19}$ In our series, we detected a similar frequency and an important association between AECA and previous CNS involvement, mainly aseptic meningitis. Reinforcing our findings, Pivetti-Pezzi et al. ${ }^{28}$ found an association between AECA and retinal vasculitis, which may also be considered as a central nervous vascular manifestation. In contrast to other studies, we did not observe an association between clinical disease activity and the presence of AECA. ${ }^{18,19}$ Regardless, it might be interesting to emphasize that, in our series, all BD patients clinically considered to have an active disease were receiving immunosuppressive drugs, which may explain the lack of association between AECA and disease activity.

Aseptic meningitis is characterized by an increase in the number of lymphocytes in the cerebrospinal fluid in the absence of a known etiologic agent. This positive relationship of AECA and CNS involvement permits us to speculate whether endothelial activation is responsible at least in part for the previously described increase in cerebrospinal fluid cellularity. Strengthening this hypothesis, Hirohata et al. ${ }^{29}$ demonstrated the clinical relevance of the presence of immunoglobulins, especially $\operatorname{IgM}$, in the cerebrospinal fluid of patients with BD and current neurological symptoms. The same findings were reproduced by Sharief et al. ${ }^{30}$ suggesting that cerebrospinal fluid immunoglobulins such as IgM and possibly IgA might be markers of acute neurological damage in BD. Therefore, the presence of AECA in our BD patients might indicate a previous CNS injury, denoting a more severe disease. In addition, the stronger association of previous CNS involvement with the IgG AECA subtype might reflect an immunological background, consequently lowering the relevance for AECA's IgM form.

In addition to the association between AECA and CNS involvement, we also observed a trend of an increased risk of aneurysms in AECA-positive patients, which was not statistically significant, probably due to the small number of cases reported. In fact, Aydintug et al. ${ }^{18}$ have already demonstrated an association of the presence of AECA in BD with vascular damage. Acute thrombosis as a manifestation of clinical activity was associated with AECA but not previous thrombosis, suggesting a more intense relationship during the acute event. On the other hand, Cervera et al. ${ }^{19}$ detected AECA in all four BD patients with a previous history of thrombotic events.

Enhanced inflammatory response and over-expression of pro-inflammatory cytokines are the prominent features of BD. ${ }^{26}$ There is also evidence of antigen-driven immune responses in $\mathrm{BD}$, but this possibly develops on the background of enhanced innate immune reactivity. ${ }^{26}$ Delineation of the similarities of BD to other AECA positive auto-inflammatory diseases may help to clarify its pathogenesis and identify missing links in the shared inflammatory and/or thrombotic pathways, leading towards a better delineation of the varied and complex manifestations presented by BD patients.

In conclusion, we should emphasize that, independently of the role AECA antibodies may have in the pathogenesis of BD, they might be a marker of more severe disease. Consequently, prospective studies involving AECA-positive BD patients may be necessary to effectively prove such a relationship. 
Christmann de Souza RB, Lage L, Goldenstein-Schainberg C, Macedo AR, Carrasco S, Gonçalves CR. Anticorpos anticélula-endothelial e envolvimento do sistema nervoso central na moléstia de Behçet. Clinics. 2007;62(6):685-90.

INTRODUÇÃO: Estudos anteriores detectaram a presence de anticorpos anti-célula endotelial (AACE) em pacientes com doença de Behçet, porém não há nenhuma evidência se a presença destes anticorpos exerce alguma influência na apresentação clínica ou atividade da doença.

OBJETIVOS: Determinar a freqüência de AACE em pacientes com doença de Behçet e analisar possíveis associações clínicas.

MÉTODOS: Foram selecionados 50 pacientes que preencheram corretamente os critérios diagnósticos para a doença de Behçet. Trinta e sete pacientes eram do sexo feminino e 13 do sexo masculino, média de idade de $44 \pm$ 9 anos e tempo médio de seguimento de $10 \pm 7,5$ anos. O AACE foram analisados por ELISA utilizando células ECV304 como substrato antigênico. A prevalência de AACE foi determinada e foram investigadas possíveis relações com características clínicas atuais e pregressas.

RESULTADOS: Os AACE foram detectados no soro de $38 \%$ dos pacientes (13 na forma $\operatorname{IgG}, 4 \operatorname{IgM}$ e 2 nas formas IgG e IgM). Observamos uma associação entre o AACE e história pregressa de envolvimento de sistema nervoso central $(\mathrm{OR}=5,4 ; \mathrm{p}=0,03)$. Esta associação era mais evidente para o AACE na forma $\operatorname{IgG}(\mathrm{OR}=6,0 ; \mathrm{p}=0,02)$. Observamos também uma tendência de risco aumentado de aneurismas em pacientes com AACE na forma $\operatorname{IgG}(\mathrm{OR}=2,58 ; \mathrm{p}=0,77)$. Nenhuma outra característica clínica mostrou-se relevante com o anticorpo estudado.

CONCLUSÃO: Nossos dados sugerem que o AACE na forma IgG pode ser uma marcador de lesão mais grave em pacientes com doença de Behçet baseado no fato de encontrarmos uma maior frequiência de história pregressa de manifestação de sistema nervoso central em pacientes com AACE circulante.

UNITERMOS: Doença de Behçet. Anticorpo anti-célula endotelial. Sistema nervoso central. Prevalência. Atividade clínica de doença.

\section{REFERENCES}

1. Shimizu T, Erlich GE, Inaba G, Hayashi K. Behçet's disease. Sem Arthritis Rheum.1979;8:223-60.

2. Nazarro P. Cutaneous manifestations of Behçet's disease - Clinical and histopathological findings. In Monacelli M, Nazarro P, eds "Behçet's Disease" (M. Monacelli and P. Nazaro, Eds), pp.15-43, Karger, Basel/ New York.1966.

3. Bang D, Honma T, Saito T, Nakagawa S, Ueki H, Lee S. Ultrastructure of vascular changes in cutaneous manifestations of Behçet's Disease. Acta Dermatol. Venerol. (Stockholm).1998;63:33-40.

4. O'Duffy JD. Vasculitis in Behçet's Disease. Rheum. Dis. Clin. North Am. 1990;16:423-431.

5. Calamia, KT, Schirmer M, Melikoglu M. Major vessel involvement in Behçet disease. Curr Opin Rheumatol.2004;17:1-8.

6. Orem A, Ertuk M, Cimsit G, Kural BV. Effect of plasma from patients with Behçet disease on the production of nitric oxide in cultured human umbilical vein endothelial cells. Med Princ Pract.2004;13:35-8.
7. Chambers JC Haskard DO, Kooner JS. Vascular endothelial function and oxidative stress mechanisms in patients with Behçet's syndrome. J Am Coll Cardiol.2001;37:517-520.

8. Probs K, Fijnheer R, Rothova A. Endothelial cell activation and hypercoagulability in ocular Behçet's disease. Am J Ophthalmol.2004;137:850-87.

9. Koç Y, Güllü I, Akpek G, Akpolat T, Kansu E, Kiraz S et al. Vascular involvement in Behçet's Disease. J Rheumatol.1992;19:402-410.

10. Rosenbaum J, Pottinger BE, Woo P, Black CM, Loizou S, Byron MA, et al. Measurement and characterization of circulating anti-endothelial cell IgG in connective tissue diseases. Clin Exp Immunol.1988;72:450-6.

11. Meroni PL, Khamashta MA, Youinou P, Shoenfeld Y. Mosaic of antiendothelial antibodies. Review of the first international workshop on antiendothelial antibodies: clinical and pathological significance Milan 9, November 1994. Lupus.1995;4:95-9. 
12. Navarro M, Cervera R, Font J, Reverter JC, Monteagudo J, Escolar G, et al. Anti-endothelial cell antibodies in systemic autoimmune diseases: prevalence and clinical significance. Lupus.1997;6:521-6.

13. Heurkens AH, Hiemstra PS, Lafeber GJ, Daha MR, Breedveld FC. Antiendothelial cell antibodies in patients with rheumatoid arthritis complicated by vasculitis. Clin Exp Immunol.1989;78:7-12.

14. Cines DB, Lyss AP, Reeber M, Bina M, DeHoratius RJ. Presence of complement-fixing anti-endothelial cell antibodies in systemic lupus erythematosus. J Clin Invest.1984;73:611-25.

15. Praprotnik S, Blank M, Meroni PL, Rozman B, Eldor A, Shoenfeld Y. Classification of anti-endothelial cell antibodies into antibodies against microvascular and macrovascular endothelial cells: the pathogenic and diagnostic implications. Arthritis Rheum. 2001;44:1484-94.

${ }^{2} 6$. Del Papa N, Guidali L, Sala A, Buccellati C, Khamashta MA, Ichikawa $\mathrm{K}$, et al. Endothelial cells as target for antiphospholipid antibodies. Human polyclonal and monoclonal anti-beta 2-glycoprotein I antibodies react in vitro with endothelial cells through adherent beta 2-glycoprotein I and induce endothelial activation. Arthritis Rheum.1997;40:551-61.

17. Nylander Lundqvist E, Back O, Nilsson TK, Rantapaa-Dahlqvist S. Prevalence of anti-endothelial cell antibodies in patients with autoimmune diseases. Clin Rheumatol.1992;11:248-53.

18. Aydintug AO, Tokgoz G, DÇruz DP, Gurler A, Cervera R, Duzgun N, et al. Antibodies to endothelial cells in patients with Behçet's disease. Clin Immunol Immunopathol.1993;67:157-62.

19. Cervera R, Navarro M, Lopez-Soto A, Cid MC, Font J, Esparza J et al. Antibodies to endothelial cells in Behçet's disease: cell-binding heterogeneity and association with clinical activity. Ann Rheum Dis. 1994;53:265-67.

20. Criteria for diagnosis of Behcet's disease. International Study Group for Behcet's Disease. Lancet.1990;335:1078-80.
21. Kolluru GK, Tamilarasan KP, Geetha Priya S, Durgha NP, Chatterjee S Cadmium induced endothelial dysfunction: consequence of defective migratory pattern of endothelial cells in association with poor nitric oxide availability under cadmium challenge. Cell Biol Int.2006;30:427-38.

22. Tamilarasan KP, Kolluru GK, Rajaram M, Indhumathy M, Saranya R, Chatterjee $\mathrm{S}$. Thalidomide attenuates nitric oxide mediated angiogenesis by blocking migration of endothelial cells. BMC Cell Biol.2006;7:17.

23. Brodin E, Iversen N, Hansen JB. Impact of native VLDL on tissue factor pathway inhibitor in endothelial cells and interactions between TFPI and lipoprotein lipase. J Lab Clin Med. 2006;147:167-73.

24. Lee KH; Bang D; Choi ES; Chun WH; Lee ES; Lee S. Presence of circulating antibodies to a disease-specific antigen on cultured human dermal microvascular endothelial cells in patients with Behçet's disease. Arch Dermatol Res.1999;291:374-81.

25. Damianovich M, Gilburd B, George J, Del Papa N, Afek A, Goldberg I, et al. Pathogenic role of anti-endothelial cell antibodies in vasculitis. An idiotypic experimental model. J Immunol.1996;156:4946-51.

26. Emmi L, Brugnolo F, Salvati G, Marchione T. Immunopathological aspects of Behçet's disease (editorial). Clin Exp Rheumatol.1995;13:687-691.

27. Haznedaroglu IC, Özdemir O, Özcebe O, Dündar SV, Kirazli S Circulating thrombomodulin as a clue of endothelial damage in Behçet's disease. Thromb Haemost.1996;75:974.

28. Pivetti-Pezzi P, Priori R, Catarinelli G, Meroni PL, Federici AB, Abdulaziz $\mathrm{M}$, et al. Markers of vascular injury in Behcet's disease associated with retinal vasculitis. Ann Ophthalmol.1992;24:411-4.

29. Hirohata S, Takeuchu A, Miyamito T. Association of cerebrospinal fluid IgM index with central nervous system involvement in Behçet's disease. Arthritis Rheum.1986;29:793-6.

30. Sharief MK, Hentges R, Thomas E. Significance of CSF immunoglobulins in monitoring neurologic disease activity in Behçet's disease. Neurology.1991;41:1398-01. 